\title{
The Impact of the Industry 4.0 Concept on Slovak Business Sustainability within the Issue of the Pandemic Outbreak
}

\author{
Adriana Grenčíková, Marcel Kordoš *D, Jozef Bartek and Vladislav Berkovič \\ Faculty of Social and Economic Relations, Alexander Dubček University in Trenčín, 91150 Trenčín, Slovakia; \\ adriana.grencikova@tnuni.sk (A.G.); jozef.bartek@tnuni.sk (J.B.); vladislav.berkovic@tnuni.sk (V.B.) \\ * Correspondence: marcel.kordos@tnuni.sk; Tel.: +421-32-7400470
}

Citation: Grenčíková, A.; Kordoš, M. Bartek, J.; Berkovič, V. The Impact of the Industry 4.0 Concept on Slovak Business Sustainability within the Issue of the Pandemic Outbreak. Sustainability 2021, 13, 4975. https:// doi.org/10.3390/su13094975

Academic Editor: Ladislav Mura

Received: 24 March 2021

Accepted: 26 April 2021

Published: 29 April 2021

Publisher's Note: MDPI stays neutral with regard to jurisdictional claims in published maps and institutional affiliations.

Copyright: (c) 2021 by the authors. Licensee MDPI, Basel, Switzerland. This article is an open access article distributed under the terms and conditions of the Creative Commons Attribution (CC BY) license (https:// creativecommons.org/licenses/by/ $4.0 /)$.

\begin{abstract}
Many studies have found that the most significant job structure changes in the Slovak business environment can be expected in production and logistics. The biggest manpower shortages are in the fields of mechanical engineering, production, construction, information sciences and communication technologies, and medical sciences. The smallest manpower shortage can be found in the humanities and social science areas. The main objective of this research was to assess the trends within the Slovak labor market from the perspective of the companies that participated in a survey focused on their assumptions on job structure changes in the context of the implementation of the elements of Industry 4.0. The estimation was based on a questionnaire conducted during the spring months of 2020 with the participation of 175 companies and institutions. The results showed that one third of companies anticipate job cuts in the implementation of smart industry. Along with the job position disposal and the qualified staffs' need for new jobs, the demands of employers regarding the level of education are growing. On the other hand, three quarters of companies are not only willing but also ready to participate in human resource vocational training and requalification focused mainly on technical skills.
\end{abstract}

Keywords: smart industry; human resources; job structure; labor market; Slovak business environment

\section{Introduction}

The sustainable business and labor market trends development in 2020 were affected worldwide by the outbreak of the COVID-19 global pandemic. However, unemployment increased only slightly from January to October 2020: in the European Union by $0.61 \%$ and in Slovakia by $0.96 \%$ [1]. Macroeconomic indicators such as a GDP measure declined sharply, reaching a low of $14 \%$ in the EU and $12.1 \%$ in Slovakia in the second quarter of 2020 [2], and gross public debt (\% of GDP) increased in the second quarter of 2020 compared to 2019 in the EU by $10.2 \%$ and in Slovakia by $11.7 \%$ [3]. In such a difficult period, employers have to respond to the current challenges. For companies in Slovakia, this is the technological challenge of implementing the elements of the Industry 4.0 concept. Based on that issue, the purpose of this paper is to examine the Industry 4.0 processes implementation from the perspective of employers in the Slovak business environment in connection with the expected trends within the labor market and job structure changes. Within the approach of companies to the implementation of Industry 4.0 elements, jeopardized jobs were indicated, and at the same time the areas in which there will be an increased demand for labor were identified. Attention will also be paid to the view of Slovak companies on the current and also future labor market trends. The novelty is to figure out the way how to use the labor force in the future within the emerging job positions as a result of putting the Industry 4.0 elements into action.

The total sample consisted of 200 respondents to whom the questionnaires were distributed. The impact was measured by a questionnaire survey, of which 175 valid responses were received, which was considered a sufficient number to meet the paper's goal. Based 
on the available information and data obtained from the conducted questionnaire survey, the situation of the Slovak labor market and employers' problems related to the assumption of job structure changes in the context of the Industry 4.0 implementation process was analyzed. Specifically, the uniqueness lies in the issue of the way in which we can define the requirements for the labor market to be set for the future under the influence of Industry 4.0 implementation within the issue of the global Covid-19 pandemic outbreak. The outline of this paper features, at the beginning, a short introduction and a literature review in Sections 1 and 2, followed by the proposed goal and research methodology in Section 3. Finally, the results are presented and discussed in Sections 4 and 5, ending with brief Conclusions.

\section{Literature Review}

The COVID-19 pandemic outbreak has not only affected the health care sector and the population's health but is also influencing employment and the movement of the labor market. The rise in unemployment in Europe is the most obvious consequence of the economic slowdown associated with the COVID-19 crisis (p. 150, [4]). Some authors comment on labor market development in terms of the COVID-19 pandemic as a gigantic crisis and predict its growing polarization to high-paid work and a group of jobs that disappear because they are uninteresting or poorly valued (pp. 40-43, [5]) (p. 2, [6]).

Authors dealing with the impacts of economic or ecological, global or regional crises of the labor market have brought important findings that can be applied in the future to the Slovak labor market. Since the financial crisis in 2008, investors' interest has shifted from job creation to investment in high-tech activities, and thus in the employment of highly qualified human resources, and as Europe's developing regions do not have enough of them, they lose sui generis investments (p. 107, [7]). In the periods of economic recessions (1979 and 2008) more effective candidates enter the labor market to become the next leaders in the business area than during the non-recessive years, mainly due to the reduction of alternative employment opportunities (pp. 488-489, [8]). Declining interest in the labor force within the local labor market regarding the outflow of highly skilled labor is increasing, while low-skilled labor remains in home countries due to falling housing prices and social benefits (p. 722, [9]). There is a significant positive correlation between pessimistically expected unemployment and real unemployment (p. 1, [10]), however after the financial crisis in 2008 there should have been a shift within the labor market from the use of cheap labor to competitiveness built on qualified human resources (p. 301, [11]).

The specifics of the Slovak labor market within the European context are decisive with regard to its trends. According to the OECD Labor Strategy, three objectives are important for the labor market's balance and the growth of inclusion and welfare resulting from employment: more and better-quality jobs, inclusion in the labor market, and adaptability and flexibility (p. 47, [12]). While assessing the institutional setting in Europe in terms of finance, work and education, it was found that Eastern and Central European countries, including Slovakia, are characterized by: being set to attract international companies, the weak protection of employees against dismissal, restrictive institutions of the financial market, a highly regulated labor market, an education system providing basic skills, and international legal frameworks that makes it difficult for companies to work together (pp. 10-82, [13]). The labor market regulations in 29 European countries have a positive effect on decisions to run businesses (p. 465, [14]). The current labor market trend is characterized by independence from lifelong employment for a single employer, and it is not only the salary being decisive but also the quality of relationships at the workplace (p. 26, [15]). Due to changes in society and technologies, employees are plagued by uncertainty about the future, and are exposed to the probability of performing various work activities (p. 228, [16]).

The issue of the process of Industry 4.0 implementation is often discussed in connection with various areas, and the labor market is one of them. The term Industry 4.0 includes a fusion of digital, biological and physical elements (p. 1378, [17]) (p. 372 [18]) 
(p. 475 [19]). In the context of the changes and implementation of Industry 4.0 in Slovakia, there is the opportunity to saturate the labor market with qualified human resources within the improvement of the education system in terms of Information and Communication Technologies (ICT) specialization (p. 80, [20]). There can be seen an opportunity to shape the workforce for the future in order to prevent rising unemployment and social inequality (p. 51, [21]). The development of Industry 4.0 brings changes due to bigger demands on competencies and education (p. 38, [22]) (p. 42, [23]), labor flexibility (p. 113, [24]) and, at the same time, the values and habits of people (p. 223, [25]). In Slovakia, due to the transformation of industry, secondary education is required in particular (p. 414, [26]) (p. 223, [27]); however, less qualified workers with low digital skills and aged 50+ will be at risk (p. 280, [28]). Industry 4.0 allows manufacturers to take their production lines to a higher technological level through complete system integration and networking. Industry 4.0 has decentralized analytics, critical decision-making, and an increase in response time during productions. Industry 4.0 solutions allow for communication between man and machine, giving wide opportunities to reduce production costs. Industry 4.0 integrates employees and digitally controlled machines with the Internet and information technologies. In the new paradigm of Industry 4.0, the most optimal solution is machine learning and deep learning, which uses large datasets for the optimization process, and obtains innovative solutions and new insights [29]. Within the business environment, the concept of Industry 4.0 is inextricably correlated with, e.g., the Internet of Things, machine-tomachine (M2M) technology, and machine learning (ML), which allow for constant contact between machines, people, products, and even production materials. The implementation of Industry 4.0 in a production company allows it to expand production capabilities, increase efficiency, and shorten the time of breaks or even eliminate them. As digitization continues, production models are changing through the use of intelligent technologies such as robotics, artificial intelligence (AI), Internet of Things (IoT), M2M, and machine learning, etc. Artificial intelligence and its techniques and machine learning algorithms give huge possibilities to predict and improve outcomes, and to better generalize the dataset in current business processes [30].

\section{Materials and Methods}

This paper will try to fill the research gap within Industry 4.0 challenges in the social and economic area. The area of changes within the introduction of Industry 4.0 is often assessed in the context of technical impacts in industry, and much less often the impacts in the socioeconomic area are assessed, especially the impacts on the labor market. It is important to investigate the effects of Industry 4.0 implementation on the labor market in the context of companies' readiness to introduce new technologies. Businesses should be able to train their employees so that they are fit for new types of jobs, and could thus prevent redundancies and rising unemployment as a national economic problem. The main objectives, aims and contributions of this paper to the social and economic field are the assessment of the issue how businesses face the challenge of saving cost within the creation of new jobs and the disposal of old jobs as a result of the process of the implementation of Industry 4.0 elements. Instead of laying off employees, employers should be able to adapt them and prepare them for new jobs being created as the consequence of the implementation of new technologies within the Industry 4.0 process.

The main goal of this paper is to assess the trends within the Slovak labor market from the perspective of companies regarding job structure changes in the context of the implementation of Industry 4.0 elements. The main research aims are to identify the following: the impact of the introduction of Industry 4.0 depending on the size of the company; the staff shortages according to education; the priority areas in education; changes within the needs of workers after Industry 4.0 implementation; the changes in the need for staff numbers; how the readiness of employers in the context of changes in Industry 4.0 is perceived. 
Based on the data obtained from the participating companies, the survey aims to create a presumption of changes in the structure of jobs in the future, both with regard to the current state of the workforce, its inadequacy, and employers' expectations, as well as defining the most probable future requirements for the labor market to be set adequately for the future under the influence of the Industry 4.0 implementation process. In order to find out the current state and expectations of employers in the industry, a survey of opinions was chosen and a questionnaire survey was used as the principal method. The questionnaire was created by the research team within the Vega 1/0462/20 project. The questionnaire method was used as the most effective one for the mass and quick survey of facts, opinions, attitudes, preferences, values, motives, needs and interests, etc. (p. 280, [31]).

Our research was classified as qualitative because we aimed to study the questionnaire outcomes instead of the mathematical significance of the variables' relationships. The continuous increase of interest in the world of science in qualitative research in the field of management sciences, which is clearly observed in recent decades, confirms the growing importance of qualitative research in relation to issues related to organizational and management matters. Qualitative research is characterized by research questions being formulated, and then by generalizations being formulated on the basis of empirical research. During the interviews, a structured questionnaire with questions was used, in which the relationships between the enterprise and its macro-environment were referred to. Nowadays, very often, survey interviews take place via the Internet. Qualitative research is used to generalize an understanding of the occurring phenomena [32].

The survey was conducted in 2020. The questionnaire was distributed to 200 companies and was answered by 175 companies. In 2020, 175 companies and institutions were involved in the survey, of which more than half-almost 55\%-were small businesses with up to 50 employees, $20 \%$ of all who received questionnaires were from medium-sized enterprises, and large enterprises accounted for $25 \%$ of the sample being examined. Based on the mentioned issue, the division is defined as follows: companies with up to $9 \mathrm{em}-$ ployees are family businesses, enterprises with 10 to 49 employees are small enterprises, enterprises with 50 to 249 employees are medium-sized enterprises, and enterprises with more than 250 employees are large enterprises. Within this breakdown, for simplification, the turnover of the company was not taken into account, because the research deals with the expected changes within the number and qualification of employees in companies.

The questionnaire was created and then implemented via the Internet as a website. The respondents who received an e-mail invitation could connect to this page via the Internet and fill in the individual questions electronically. Through the questionnaire, industrial companies in Slovakia were contacted by e-mail, in person, or by telephone, and were asked to comment on individual questions of the questionnaire. The questionnaire sample size was set within the Vega project framework. In terms of this particular survey, no hypothesis was set. The structure of the questions within the questionnaire was outlined according to the Vega project settings. The original condition, or rather the intention, to select a sample of respondents was that the company is operating in the field of industry. Due to the fact that this condition could not have been met, information from areas other than industry was also obtained, which was beneficial in the final investigation, and therefore these companies were not excluded from the sample being assessed. Every company that received an invitation to participate in the research had to be registered in the Commercial Register of the Slovak Republic.

\section{Results}

The course of the questionnaire survey was also influenced by the deteriorating epidemiological situation in the Slovak Republic, which from 13 March 2020 gradually paralyzed many areas of economic life. Schools, shops, service facilities and eventually many businesses were closed. This is why it can be assumed that the results of this questionnaire survey were significantly affected by the current situation, and it also reflects significant changes in priorities that companies in such a situation were forced to consider. 
Gradually, the possibilities of teaching, working and conducting state administration services using online platforms were ascertained and verified. This step-by-step switch verified the readiness of individual areas for the shift to such a mode, which also revealed weaknesses of organizations and examined their possibilities for rapid adaptation to new conditions. The size structure of the enterprises (organizations) shown in Figure 1 illustrates the largest share of small enterprises involved in the survey, followed by a quarter share of large companies, while the group of medium-sized companies had the smallest share.

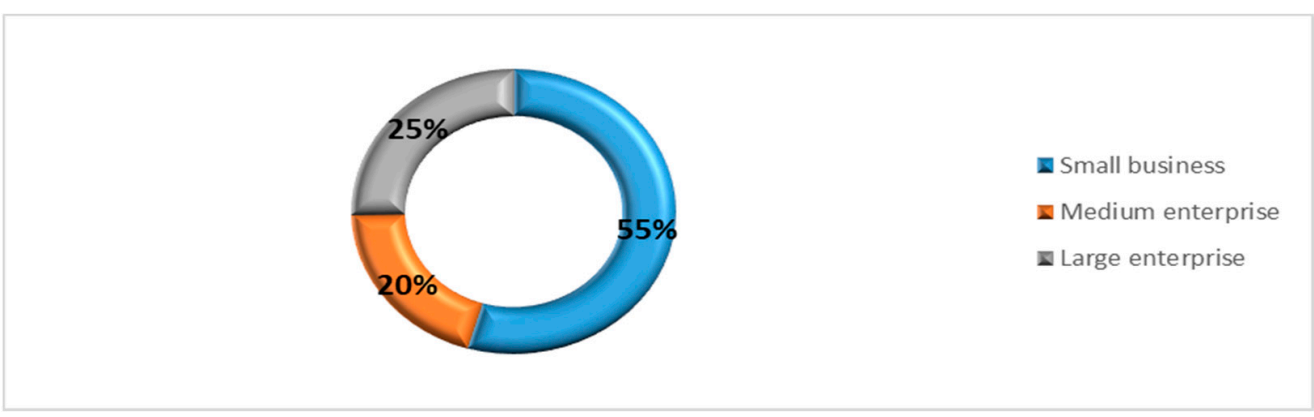

Figure 1. Breakdown of the enterprises (organizations) by the size. Source: our own processing.

The questionnaire was filled in by companies from different areas and sectors of the Slovak economy, supporting the relevance of this questionnaire. Its structure partly corresponds to the division of the significant industries of the economy in the Slovak Republic. The data from Figure 2 show that one of the most significant sectors represented in the survey was the industrial production sector, which in terms of the Slovak Republic also has the most significant share in GDP creation. These respondents accounted for almost one third of all of the respondents. Construction, retail, wholesale, transport and storage and, finally, administrative and support services also had a significant appearance.

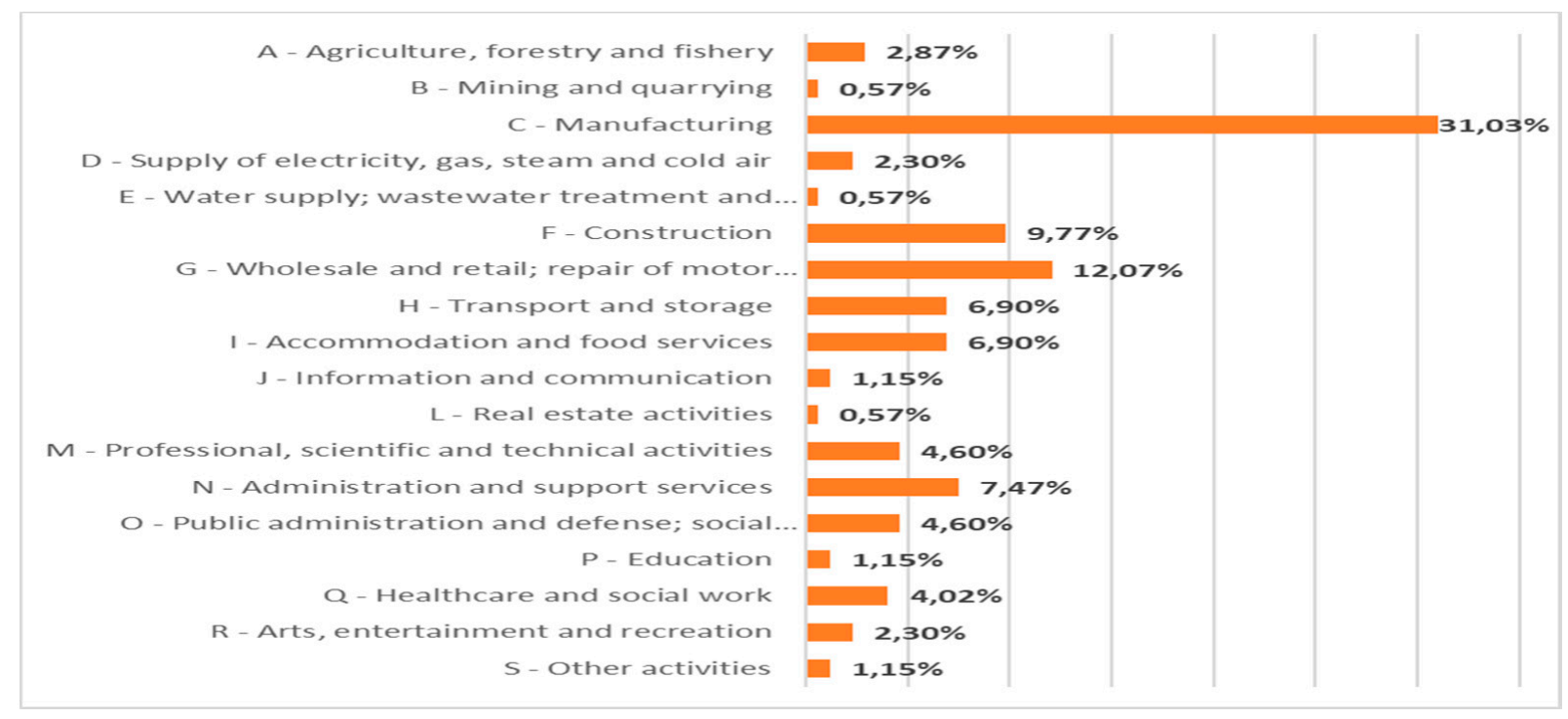

Figure 2. Main operation areas of the organizations. Source: Own processing.

In order to better depict the current situation of the labor market, the respondents were asked-what types of workers, according to education, are currently missed the most, i.e., of what is there an acute shortage within all enterprises. The survey was conducted in the months from March to May 2020, and outcomes of this issue are presented in Figure 3. Based on the data from the questionnaire, the classification structure had two dimensions, i.e., one according to the level of education, from secondary to higher education, and the 
other represented by the field of education. These results point out how satisfactory the structure of education is in the conditions of the Slovak Republic, and partly they give an idea of the direction in which the educational structure should change in the short term. This can be achieved by supporting the study programs within the level of education, in which employers feel a shortage, and by adjusting or limiting the expansion of study fields that are not of interest within the labor market.

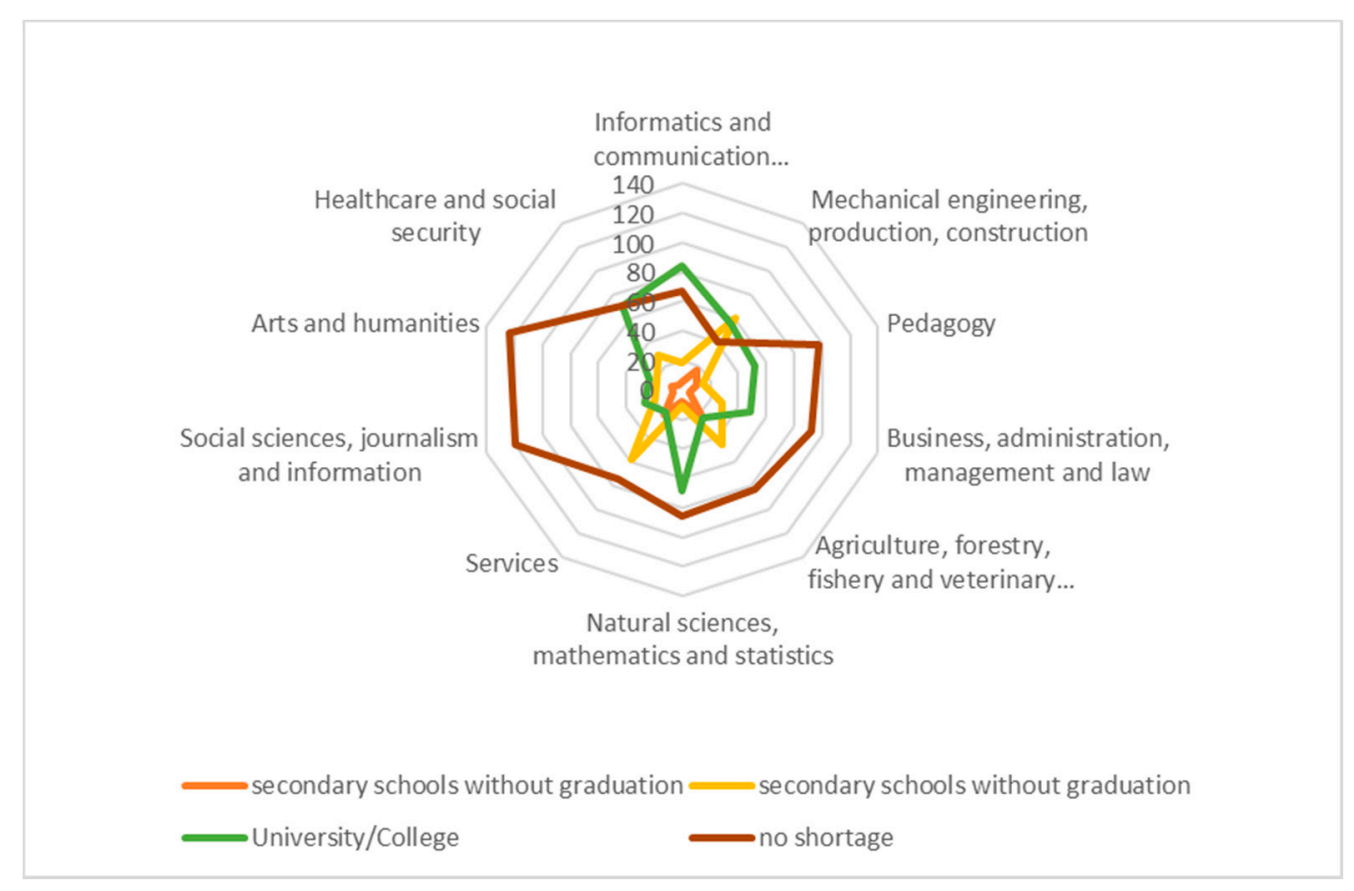

Figure 3. The shortage of workers by education. Source: our own processing.

Figure 3 illustrates the shortage of workers by education in all enterprises, regardless of the size and field of the business, such that it is the sum of all respondents. According to Figure 3, the biggest shortage of manpower is clearly for workers in the field of engineering, production and construction. This sector shows an enormous shortage of workers cumulatively, up to the level of almost $80 \%$. The most wanted workers, in almost the same proportion, are employees from this field with a university and a full secondary education degree in the ratio of $70 \%$, and there is a claim also for $10 \%$ of employees with a secondary vocational education without a high school diploma; $20 \%$ of companies are not interested in workers from this field of education, which is natural due to the structure of companies in the economy and the structure of the respondents. The second area where the biggest demand for labor has emerged are the areas of information science and communication technologies. Here, the demand is more oriented for university-educated workers, which represents up to three quarters of the total demand. The total demand for ICT workers is at the level of $62 \%$, which means that two out of three companies have a problem with acquiring workers in this field of education. Another important area where employers experience a shortage of workers are the health care and social services sectors. The demand for workers in this field of education can also be linked to the current pandemic situation in Slovakia and in the world, where the onslaught on the health care system has revealed its labor supply weaknesses and highlighted the previously emerging shortage of workers in health care and social care services. Furthermore, considering the fact that $30 \%$ of industrial enterprises, which are unlikely to look for health care and social security workers, took part in the survey, it can be said that the demand for workers in this field is extremely high. Other fields of education, where the vast majority of employers experience a shortage of workers, are services, science, mathematics and statistics, agriculture, forestry, fisheries, and veterinary medicine. At the other end of the spectrum there are the fields of education where employers experience the least shortages. They are workers with arts 
and humanities education, as well as graduates of social sciences and journalism. In both cases, almost $70 \%$ of respondents do not feel deficient in the staff who studied these fields of study. To sum up these results, while looking at all companies, the Slovak labor market primarily needs technical staff from the fields of engineering, manufacturing, construction, information science and communication technology professionals, and professionals in all areas of health care and social services.

The next part of the survey showed the fields in which and the levels of education at which it is necessary to support and expand the education for future workers, and also to train or retrain the free labor force of the labor market, as well as current employees. The survey results also demonstrate the fields of education where the demand for workers is not high, especially in the areas of social sciences, administration and law, pedagogy, natural sciences and statistics. Traditionally, the high demand for an educated workforce is in the field of informatics, engineering production and construction, which also corresponds to the orientation of Slovak industry.

If we want to know in which direction the implementation of the smart industry elements of Industry 4.0 will go, i.e., which areas of the corporate structure will be a priority for the implementation of Industry 4.0, it is necessary to know what companies prefer. From Figure 4, it can be seen that due to the structure of the Slovak economy, the global trend, and last but not least the name of this phase of the technical revolution (Industry 4.0), it is not surprising that respondents highlighted production as the main reason for introducing Industry 4.0 in all companies, regardless of their size: they see Industry 4.0 as the main implementation area. The next area after production is logistics in terms of medium and large companies. These companies realize that the optimal flow of goods, materials and services will be, in addition to improved production, the key issue to maintain the company's competitiveness. On the other hand, in the case of small businesses, the area of communication with the customer came in second place.

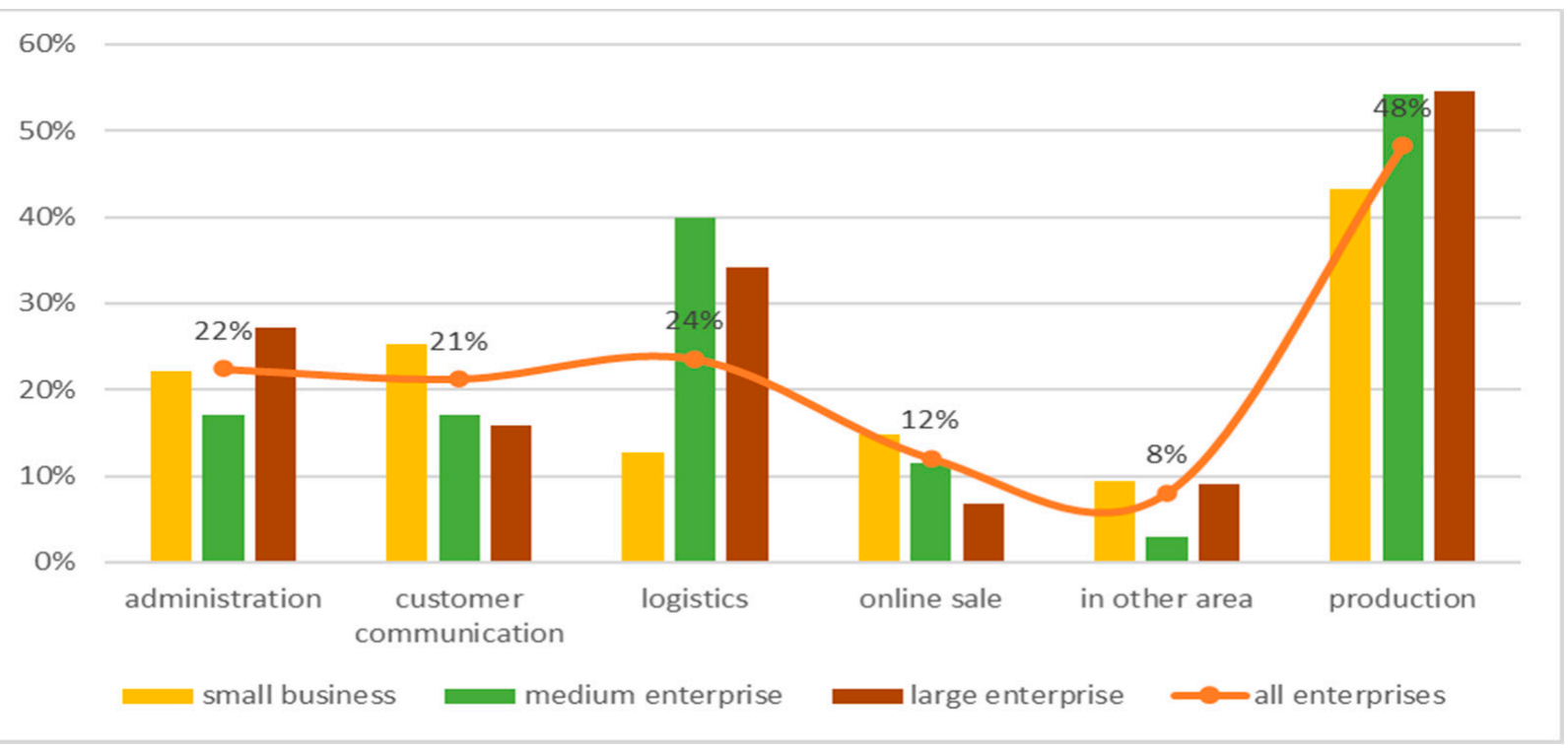

Figure 4. Priority areas for Industry 4.0 implementation (company digitalization). Source: our own processing.

Figure 4 is designed to compare the average value of all companies with the opinion of individual companies being sorted out by the size. In the area of customer communication, it is clear that small businesses will be particularly interested in having the smart industry elements help them, especially in the area of customer communication. The third spot was taken by Industry 4.0 implementation in the field of administration. Businesses are already processing ever-increasing volumes of data, and more and more effort is required to manage it. It is not realistic or economical for companies to hire more and more administrative staff to process ever-increasing data, so a new solution is being searched for. In the future, this 
can only be solved by automation processes: not by automation using machine processing, but automation using artificial intelligence, where many routine tasks and decisions will be made by devices with artificial intelligence. For small businesses, the area of online sales is far too important within the Industry 4.0 implementation process.

From the data obtained from the companies participating in the survey, the task is to create an assumption within the job structure changes in the future under the process of the implementation of Industry 4.0 elements; the views of all of the companies on job structure changes were divided into five categories, two of which were administrative non-production categories and three categories were manufacturing or providing various services.

The survey results in Figure 5 indicate that within the administrative staff category, based on the responses of all of the enterprises, it is assumed that $56 \%$ of jobs do not expect any changes. In total, $11 \%$ of all companies expect an increase in jobs and thus increased demand for an administrative workforce, but most importantly, 33\% of all companies expect fewer employees to implement a smart industry. It can be understood that if, in $56 \%$ of companies, there is no change in employment in this position and the increased need is reported by $11 \%$ and a decrease of $33 \%$, the balance of labor demand for this group of workers is at the level of $22 \%$. This probably does not mean that $22 \%$ of administrative staff in all companies will lose their jobs. However, this means this large group will have to change their job application, whether in the context of changing the job position in a company, by increasing or switching qualification to another, more desirable expertise, or especially adapting their skills and abilities to new labor market requirements.

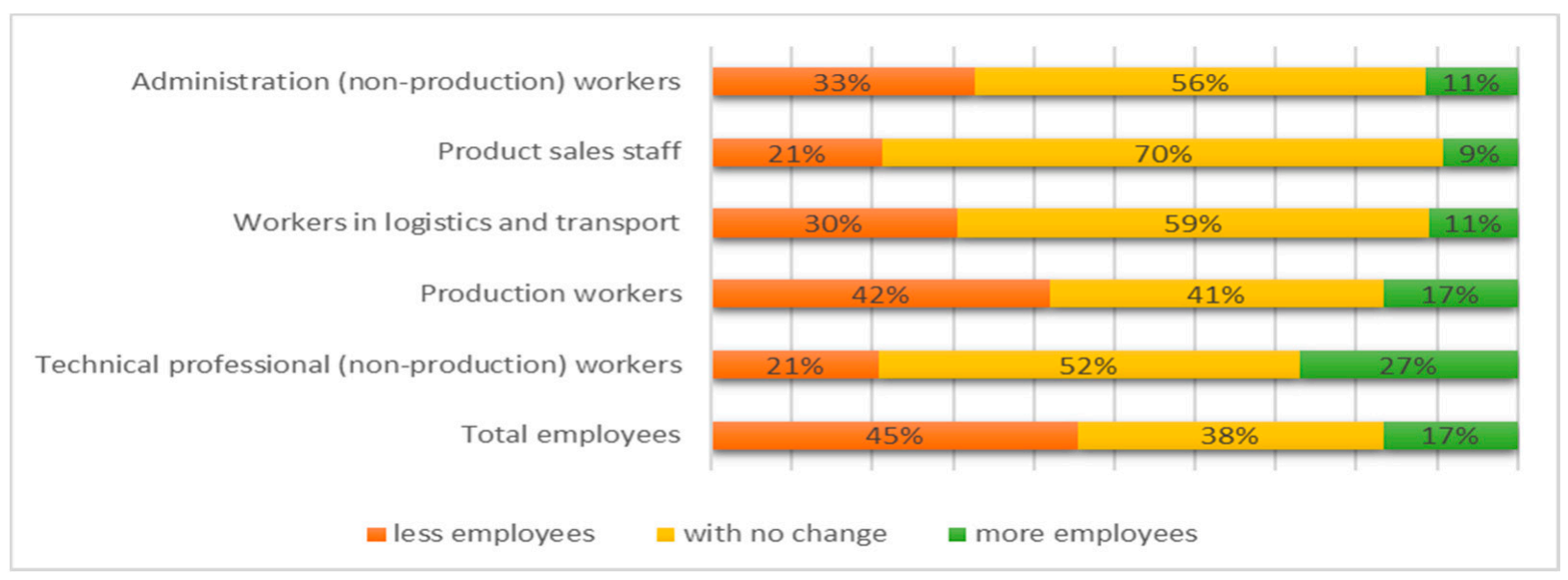

Figure 5. Change in the need for employees after Industry 4.0 implementation. Source: our own processing.

The same assumption is also made for other jobs, where the balance of demand for labor among workers in selling products is at the level of $12 \%$. For workers in logistics and transport, a balance of $19 \%$ is expected; for workers in production, it is $25 \%$. For technical workers, the balance of labor demand is even positive, at $6 \%$. In order to get an idea of what percentage of workers' jobs are at risk, it is necessary to find out the structure of jobs in the economy, both on the basis of the companies' size and also by job classification. The Statistical Office of the Slovak Republic does not have such a structured database, but it is certainly possible to apply this forecast to individual enterprises separately, so that the future of jobs can be at least partially shown. Enterprises have their own and often very accurate statistics on job structure, so these predictions can give the most relevant outputs from enterprise statistics.

The question of preparing the current, but especially the future, workforce for professions in the future is crucial in terms of readiness to enter the Industry 4.0 era. The unprecedented speed with which Industry 4.0 can affect the way organizations and businesses operate can make us unprepared when underestimating this issue. When it comes 
to the adequate training of the future workforce, there are several tools available that can be used to prepare future and retrain current employees. On the positive side, three quarters of companies are not only willing but also ready to participate in this training as a part of their preparation to prepare employees for the Industry 4.0 challenges. As shown in Figure $6,29 \%$ of companies are willing to participate in education along with the education sector, and another almost $47 \%$ of companies create conditions for their employees within further education, of which $20 \%$ of companies fully fund such education.

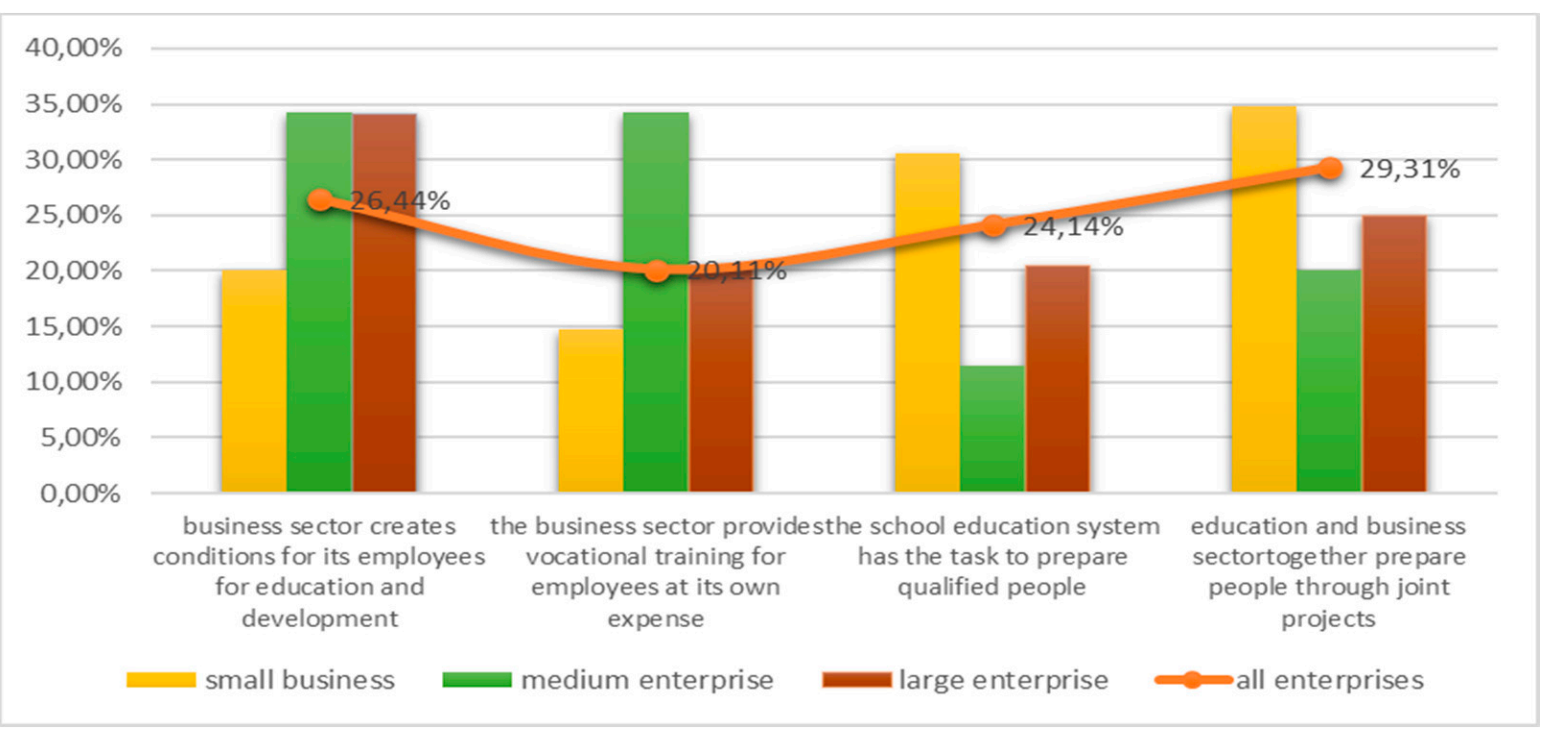

Figure 6. Preparing the employees for Industry 4.0 challenges. Source: our own processing.

Businesses, and in particular those undergoing the process of deploying smart industries, are a crucial source of information on where to focus future workforce training. Figure 7 illustrates the question regarding where the new content of education in relation to Industry 4.0 should be addressed to in particular. The vast majority of all companies agreed that training should focus mainly on technical skills. An equally important area of education, where-according to the surveyed companies-attention needs to be focused is the area of increasing the specialization in a particular discipline. This requirement sends a clear signal to the education system to focus more on technical disciplines and special vocational trainings, with professional education instead of general education.

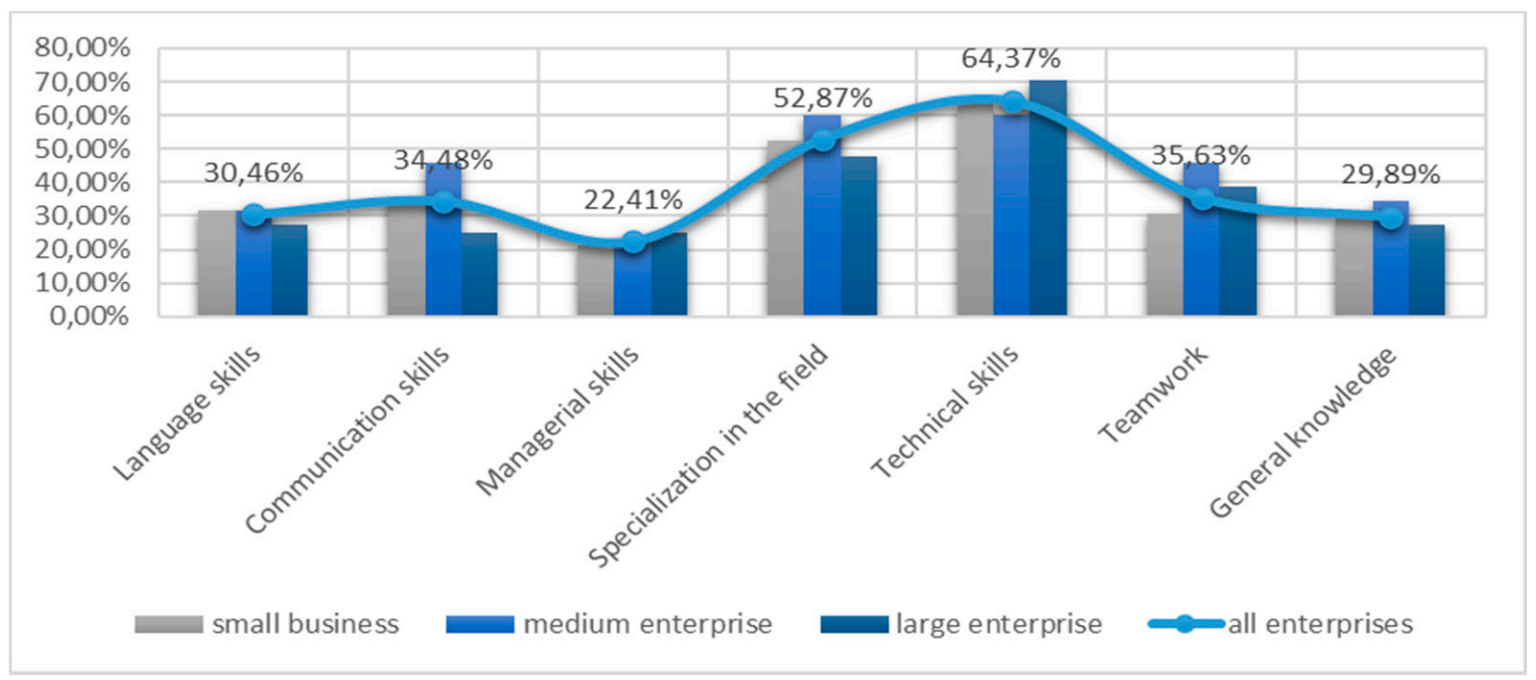

Figure 7. New content of education in terms of Industry 4.0. Source: our own processing. 


\section{Discussion}

Based on the research findings, it can be said that the concept of Industry 4.0 will significantly affect the job structure changes in general, and Slovak Republic will not stand aside. It will affect all labor market segments, not just industrial companies. The assessment of digitization and the related automation requires, above all, for us to overcome traditional infrastructural technological perspectives, and it encourages the use of more comprehensive indicators regarding diffusion and ICT usage in the economy as a whole [33,34]. The implementation of advanced communication technology platforms has already affected the significant development of tourism, banking, and trade, and will certainly affect the work changes in the public and state sectors $[35,36]$. Thanks to artificial intelligence, human labor will be reduced. It is believed that this would primarily solve the labor shortages of the labor market and the issue of the rising cost of labor. A positive effect of the labor productivity increase because of emerging new technologies will be, for example, the maintenance of the pension system, but on the other hand it would require a vigorous reform regarding the education system and vocational training, as well as the employers' approach to vocational training in the company $[37,38]$. Education in its traditional form will disappear, and attention must be focused mainly on being well orientated in the big data issue; the role of teacher will also change from mentor to coach. Authors such as Galli (2020) and Gera and Singh (2019) agree that the positive effects of digitalization can be seen in the emergence of new industries and markets, decreasing prices and increasing incomes, while noting the need to improve the skills of workers $[39,40]$. This positive impact of digitalization is prevalent in economies that are able to take advantage of opportunities offered by ICT, and these new technologies do not have a dominant impact on labor savings [41]. According to a research study on Sorgen men, they usually perform occupations that may be threatened by automation, while women perform occupations that require social tasks and are less prone to automation [42].

By and large, the research and development in the conditions of the Slovak Republic is at a low level and permanently underfunded. New technologies will increasingly displace low-skilled and physical labor, and new emerging jobs will put increasing demands on human intellect $[43,44]$. Ongoing discussions on the impact of change on employment often bring up fundamental differences between those who expect unlimited opportunities and prospects to increase workers' productivity and freedom from physical and routine work in emerging jobs, and those who expect massive compensation for human labor and the relocation of jobs to other countries $[45,46]$. The research results proved that in order to prevent this trend, it is necessary to focus on preparing the workforce for labor market conditions in the future. Changing qualifications or raising the educational level of the population will be one of the key conditions of being competitive within the global labor market. Regarding the push-pull factors in business sustainability conditions in Slovakia, people quit their employment because they are pushed to do so as a result of certain push factors, and these have fundamental influence on the decision or motivation to start their own business. The desire to have a job the individual feels positive about and which provides a possibility for self-realization can be listed among pull factors, which has a positive impact on the success of the business, and the entrepreneur encounters many obstacles [47].

There are many authors dealing with the issue of Industry 4.0, Innovation and SME. They have discovered that the significant problem in the usability of cloud platforms is the lack of support to store a digital twin, and its simulation and visualization. Industry 4.0 uses both technologies: cloud platforms for simple data storage, and digital twins for actual status visualization and simulation. Therefore, there is a need to have some connection between these technologies. They also figured out that, in the digital, narrowly specialized and advanced globalized era, the meaningfulness of value-creating activities is important for the future of business. Currently, the companies consider the meaningfulness of work and communication as the most important values of people management [48-50]. The research results presented in the papers of those authors, and in our paper in a similar 
way, describe the value profiling of companies operating in Slovakia and the values the companies consider crucial for the success of their business in the Industry 4.0 era.

Generally speaking, because of the global pandemic outbreak, Slovakia experienced an economic slowdown in 2020 compared to the previous period, but it is very difficult to predict further development. Many companies have lost their markets and become uncompetitive due to the measures taken in Germany, where a great deal of Slovak export is heading [51]. On the contrary, other companies have optimized their processes and have embarked significantly on the optimization of the human workforce, such that in case of a human factor failure, they are as prepared as possible for similar situations that are likely to recur $[52,53]$. When making these forecasts, we must not forget the fact that smart industry implementation is constantly creating new jobs that have never existed before. These positions may be directly or indirectly related to the Industry 4.0 implementation issue. Directly, the development and implementation of Industry 4.0 creates new jobs where employees find their application in a wide field of scientific and technical activities and supporting services. Indirectly, people have more free time and are willing to invest their resources into new activities that they cultivate, rather than hobbies (leisure activities, sports, education), and this opens up huge opportunities for new jobs $[54,55]$.

\section{Conclusions}

The main goal of this paper was to estimate the assumption of job structure changes in the context of Industry 4.0 implementation. We arrived at the conclusion that new technologies will increasingly displace low-skilled and physical work, and new emerging jobs will put increasing demands on the human intellect. The research findings proved that one third of companies are expecting job cuts, with job positions being replaced by smart industry implementation. With the loss of old job positions and the need for qualified staff for new ones, the demands of employers for a higher level of training are growing. It was also revealed that three quarters of companies are not only willing but also ready to participate in vocational training and retraining focused mainly on technical skills.

To summarize the results of the research, companies expect an increase in production efficiency from the introduction of intelligent industry, and see the shortage of workers as a much more complex problem that will not be solved primarily by the implementation of Industry 4.0. With the appearance of Industry 4.0 within industrial enterprises, the issue of job structure will become increasingly urgent. The research has shown that companies will focus on the professionalism of employees to be able to cope with new technologies as best they can. For these workers, there is no reason to worry about finding a job on the labor market in the future. The impact on jobs will also vary depending on the size of the companies: while small companies expect employment to be maintained, mediumsized and especially large companies will be cutting jobs, especially from the ranks of the working professions, without employment in the field of study.

As a research limitation, it should be mentioned that some answers from the questionnaire were not relevant, the statistical data varies depending on the source being used, and each organization has a different approach to processing data and information; thus, the comparison may not be too accurate. The set of companies, which were the subject of the research, is a limiting factor. In order to broaden the topic, further research will be devoted to exploring the role of the Covid-19 pandemic outbreak and its impact on the industry sector within the world economy development, particularly in the EU economy, and the performance of economies in the Central Europe region, with implications for labor market changes and social and economic development.

Author Contributions: Conceptualization, A.G. and M.K.; methodology, A.G. and M.K.; software, J.B. and V.B.; validation, A.G., M.K., J.B. and V.B.; formal analysis, A.G., M.K. and J.B.; investigation, A.G., J.B. and V.B.; resources, A.G. and M.K.; data curation, A.G., J.B. and V.B.; writing-original draft preparation, A.G. and J.B.; writing—review and editing, A.G. and M.K.; visualization, J.B. and V.B.; supervision, A.G.; project administration, M.K.; funding acquisition, M.K. All authors have read and agreed to the published version of the manuscript. 
Funding: This research was funded by the Slovak Ministry of Education's Scientific grant agency VEGA: 'Assessment changes in the qualitative structure of international economic relations under the influence of Industry 4.0 with implications for the EU and Slovak economic policies'. Project registration number: [Reg. No.: 1/0462/20].

Institutional Review Board Statement: Not applicable.

Informed Consent Statement: Not applicable.

Data Availability Statement: The data processing was based on our own research output.

Conflicts of Interest: The authors declare no conflict of interest. The funders had no role in the design of the study; in the collection, analyses, or interpretation of data; in the writing of the manuscript, or in the decision to publish the results.

\section{References}

1. Eurostat. Unemployment Rate-Total (\% Labour Force). Available online: https://ec.europa.eu/eurostat (accessed on 27 February 2020).

2. Eurostat. GDP-Volume (\% Change). Available online: https://ec.europa.eu/eurostat (accessed on 27 February 2020).

3. Eurostat. Government Gross Debt (\% GDP). Available online: https:/ / ec.europa.eu/eurostat (accessed on 27 February 2020).

4. Liotti, G. Labour market flexibility, economic crisis and youth unemployment in Italy. Struct. Chang. Econ. Dyn. 2020, 54, 150-162. [CrossRef]

5. Schwab, K.; Malleret, T. COVID-19: The Great Reset; WEF Publishing: Genova, Italy, 2020; p. 280. ISBN 2940631123.

6. Kikuchi, S.; Kitao, S.; Mikoshiba, M. Who Suffers from the COVID-19 Shocks? Labor Market Heterogeneity and Welfare Consequences in Japan. J. Jpn. Int. Econ. 2020, 59, 101117. [CrossRef]

7. Becker, B.; Driffield, N.; Lancheros, S.; Love, J.H. FDI in hot labour markets: The implications of the war for talent. J. Int. Bus. Policy 2020, 3, 107-133. [CrossRef]

8. Nagler, M.; Piopiunik, M.; West, M.R. Weak Markets, Strong Teachers: Recession at Career Start and Teacher Effectiveness. J. Labor Econ. 2020, 38, 453-500. [CrossRef]

9. Notowidigdo, M.J. The Incidence of Local Labor Demand Shocks. J. Labor Econ. 2020, 38, 687-725. [CrossRef]

10. Da Silveira, J.J.; Lima, G.T. Can workers' increased pessimism about the labor market conditions raise unemployment? Int. Rev. Econ. Financ. 2020, 72, 125-134. [CrossRef]

11. Klimko, R.; Rievajová, E. Trends in the Labour Markets of the European Union. In Proceedings of the 15th International Scientific Conference Globalization and Its Socio-Economic Consequences Proceedings (Part I.), Rajecké Teplice, Slovakia, 7-8 October 2015; ZU-University of Zilina: Žilina, Slovakia, 2015; pp. 297-302.

12. OECD. Good Jobs for All in a Changing World of Work: The OECD Jobs Strategy; OECD Publishing: Paris, France, 2018; p. 391. [CrossRef]

13. Sanders, M.; Marx, A.; Stenkula, M. (Eds.) The Entrepreneurial Society. A Reform Strategy for Italy, Germany and the UK; Springer: Berlin/Heidelberg, Germany, 2020; Volume 44, p. 252. [CrossRef]

14. Fu, K.; Larsson, A.-S.; Wennberg, K. Habitual entrepreneurs in the making: How labour market rigidity and employment affects entrepreneurial re-entry. Small Bus. Econ. 2018, 51, 465-482. [CrossRef]

15. Grenčíková, A. Nové trendy v riadení l’udských zdrojov [New trends in human resource management]. Soc. Econ. Rev. 2015, $13,26-31$.

16. Rievajová, E.; Kavec, J. Flexibilita trhu práce a ochrana zamestnanca. Econ. Rev. 2009, 38, 228-238.

17. Koišová, E.; Masárová, J.; Ivanová, E. Digital Economy in the Context of Digital Skills in the Labour Market in the Visegrad Group. In Proceedings of the 3rd International Conference Contemporary Issues In Theory and Practice of Management CITPM, Częstochowa, Poland, 23-24 April 2020; Wydawnictwo Politechniki Częstochowskiej: Czestochowa, Poland, 2020; pp. 135-142.

18. Stankevičiūtè, Ž.; Staniškienè, E. Reducing job insecurity in the light of industry 4.0: The role of sustainable HRM. In Proceedings of the Conference of the Impact of Industry 4.0 on Job Creation, Trenčin, Slovakia, 21 November 2019; FSEV TnUAD: Trenčín, Slovakia, 2020; pp. 370-381.

19. Rasca, L. Human resources challenges for the 21st century. In Proceedings of the 11th International Conference on Business Excellence, Bucharest, Romania, 30-31 March 2017; pp. 475-481.

20. Buganová, K.; Šimíčková, J. Zvyšovanie konkurencieschopnosti podnikov prostredníctvom implementácie manažmentu rizík v kontexte koncepcie Industry 4.0. In Proceedings of the Conference of the Impact of Industry 4.0 on Job Creation, Trenčin, Slovakia, 21 November 2019; FSEV TnUAD: Trenčín, Slovakia, 2020; pp. 79-86.

21. Berkovič, V.; Masárová, T.; Grenčíková, A. Vplyv industry 4.0 na zmeny v štruktúre pracovných miest. In Proceedings of the Conference of Impact of Industry 4.0 on Job Creation, Trenčín, Slovakia, 22 November 2018; FSEV TnUAD: Trenčín, Slovakia, 2020; pp. 44-52.

22. Grenčíková, A.; Berkovič, V. Vplyv INDUSTRY 4.0 na Zmeny v Štruktúre Pracovných Miest; FSEV TnUAD: Trenčín, Slovakia, 2020; p. 154. 
23. Bartek, J. Employment and life expectancy of older people in Slovakia and European Union. In Proceedings of the 3rd International Conference Contemporary Issues in Theory and Practice of Management CITPM, Częstochowa, Poland, 23-24 April 2020; Wydawnictwo Politechniki Częstochowskiej: Czestochowa, Poland, 2020; pp. 40-47.

24. Mayerová, K. Zmeny v kompetenciách pracovníkov v koncepte Industry 4.0. In Proceedings of the 3rd International Conference Contemporary Issues in Theory And Practice of Management CITPM, Częstochowa, Poland, 23-24 April 2020; Wydawnictwo Politechniki Częstochowskiej: Czestochowa, Poland, 2020; pp. 107-114.

25. Okano, M.T. Global Digital Platform for Medical Knowledge Dissemination: A Multinational Pharmaceutical Company Strategy for Digital Stakeholder Relationship Transformation. In Proceedings of the 3rd International Conference Contemporary Issues in Theory And Practice Of Management CITPM, Częstochowa, Poland, 23-24 April 2020; Wydawnictwo Politechniki Częstochowskiej: Czestochowa, Poland, 2020; pp. 223-229.

26. Tupá, M. Vplyv priemyslu 4.0 na trh práce slovenskej republiky v kontexte pracovnej migrácie. In Proceedings of the Conference of the Impact of Industry 4.0 on Job Creation, Trenčin, Slovakia, 21 November 2019; FSEV TnUAD: Trenčín, Slovakia, 2020; pp. 414-422.

27. Vojtovič, S.; Tupá, M.; Karbach, R. Pracovná imigrácia v krajinách V4 v kontexte rozvoja Industry 4.0. In Proceedings of the Conference of the Impact of Industry 4.0 on Job Creation, Trenčin, Slovakia, 21 November 2019; FSEV TnUAD: Trenčín, Slovakia, 2020; pp. 423-431.

28. Masárová, T.; Sokol, J. Zmena v zručnostiach a štruktúre profesií ako výzva vyplývajúca zo zavádzania priemyslu 4.0. In Proceedings of the Conference of the Impact of Industry 4.0 on Job Creation, Trenčin, Slovakia, 21 November 2019; FSEV TnUAD: Trenčín, Slovakia, 2020; pp. 277-283.

29. Li, Y.; Dai, J.; Cui, L. The impact of digital technologies on economic and environmental performance in the context of industry 4.0: A moderated mediation model. Int. J. Prod. Econ. 2020, 229, 107777. [CrossRef]

30. Borowski, P.F. Innovative Processes in Managing an Enterprise from the Energy and Food Sector in the Era of Industry 4.0. Processes 2021, 9, 381. [CrossRef]

31. Gavora, P. Elektronická Učebnica Pedagogického Výskumu; Univerzita Komenského: Bratislava, Slovakia, 2010.

32. Borowski, P.F. New technologies and innovative solutions in the development strategies of energy enterprises. HighTech Innov. J. 2020, 1, 39-58. [CrossRef]

33. Evangelista, R.; Guerrieri, P.; Meliciani, V. The economic impact of digital technologies in Europe. Econ. Innov. New Technol. 2014, 23, 802-824. [CrossRef]

34. Shvindina, H.O. Innovations of strategic management development: From competition to coopetition. Mark. Manag. Innov. 2017, 1, 180-192. [CrossRef]

35. Ahmad, N.; Seman, N.A.A. Industry 4.0 implications on human capital: A review. J. Stud. Manag. Plan. 2019, 4, $221-235$.

36. Müller, J.; Kiel, D. What drives the implementation of industry 4.0? The role of opportunities and challenges in the context of sustainability. Sustainability 2018, 10, 247. [CrossRef]

37. Kádár, B. Including labour market proposals in higher education offers. Acta Oecon. Univ. Selye 2017, 6, 89-100.

38. Noskova, M.; Peracek, T. Termination of employment in the Slovak Republic as a key issue of HR management. Cent. Eur. J. Labour Law Pers. Manag. 2019, 2, 44-59.

39. Galli, B.J. The Future of Economic Decision Making in Project Management. IEEE Trans. Eng. Manag. 2020, 67, 396-413. [CrossRef]

40. Gera, I.; Singh, S. A critique of economic literature on technology and fourth industrial revolution: Employment and the nature of jobs. Indian J. Labour Econ. 2019, 62, 715-729. [CrossRef]

41. OECD. ICT Skills and Employment: New Competences and Jobs for a Greener and Smarter Economy; OECD Digital Economy Papers; OECD: Paris, France, 2012; Volume 198, p. 60. [CrossRef]

42. Sorgner, A.; Bode, E.; Krieger-Boden, C.; Aneja, U.; Coleman, S.; Mishra, V.; Robb, A.M. The Effects of Digitalization on Gender Equality in the G20 Economies; Kiel Institute for the World Economy: Kiel, Germany, 2017; p. 168.

43. Jašková, D.; Havierniková, K. The human resources as an important factor of regional development. Int. J. Bus. Soc. 2020, 21, 1464-1478.

44. Korauš, A.; Kaščáková, Z.; Felcan, M. The impact of ability-enhancing HRM practices on perceived individual performance in IT industry in Slovakia. Cent. Eur. J. Labour Law Pers. Manag. 2020, 3, 33-45. [CrossRef]

45. Szeiner, Z.; Mura, L.; Horbulák, Z.; Roberson, M.; Poor, J. Management Consulting Trends in Slovakia in the Light of Global and Regional Tendencies. J. East. Eur. Cent. Asian Res. JEECAR 2020, 7, 191-204. [CrossRef]

46. Bilan, Y.; Rubanov, P.; Vasylieva, T.; Lyeonov, S. The influence of Industry 4.0 on financial services: Determinants of alternative finance development. Pol. J. Manag. Stud. 2019, 19, 70-93. [CrossRef]

47. Godany, Z.; Machova, R.; Mura, L.; Zsigmond, T. Entrepreneurship Motivation in the 21st Century in Terms of Pull and Push Factors. TEM J. Technol. Educ. Manag. Inform. 2021, 10, 334-342. [CrossRef]

48. Modrak, V.; Soltysova, Z. Management of Product Configuration Conflicts to Increase the Sustainability of Mass Customization. Sustainability 2020, 12, 3610. [CrossRef]

49. Modrak, V.; Soltysova, Z.; Onofrejova, D. Complexity Assessment of Assembly Supply Chains from the Sustainability Viewpoint. Sustainability 2019, 11, 7156. [CrossRef]

50. Židek, K.; Pite', J.; Adámek, M.; Lazorík, P.; Hošovský, A. Digital Twin of Experimental Smart Manufacturing Assembly System for Industry 4.0 Concept. Sustainability 2020, 12, 3658. [CrossRef] 
51. Dobrosotskiy, V.I.; Semenova, G.N.; Kazarinova, E.B.; Falina, N.V. Venture investments into digital education in the conditions of industry 4.0: Problems of attraction and directions of usage. Horizon 2019, 27, 213-218. [CrossRef]

52. Betakova, J.; Haviernikova, K.; Okreglicka, M.; Mynarzova, M.; Magda, R. The Role of Universities in Supporting Entrepreneurial Intentions of Students Toward Sustainable Entrepreneurship. Entrep. Sustain. Issues 2020, 8, 573-589. [CrossRef]

53. Mura, L.; Zsigmond, T.; Kovács, A.; Baloghová, É. Unemployment and GDP Relationship Analysis in the Visegrad Four Countries. Online J. Model. New Eur. 2020, 34, 118-134. [CrossRef]

54. Çera, G.; Belás, J.; Strnad, Z. Important factors which predict entrepreneur's perception in business risk. Probl. Perspect. Manag. 2019, 17, 415-429. [CrossRef]

55. Krajňákov, E.; Vojtovič, S. Struggles of older workers at the labour market. Econ. Sociol. 2017, 10, 319-333. [CrossRef] 